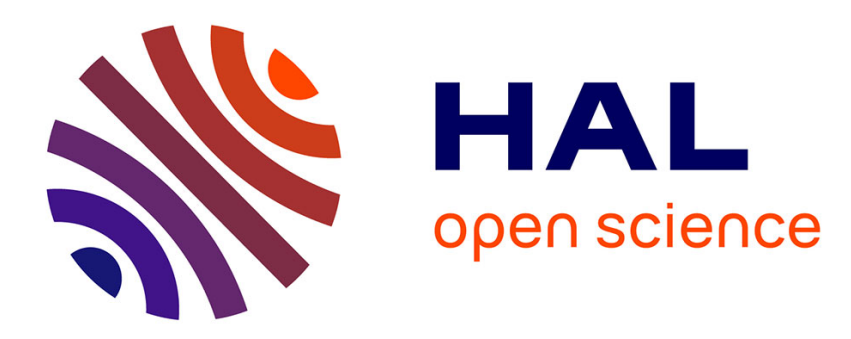

\title{
Collective Sensemaking: The Cave within the Cage
} Olivier Baly, Frédéric Kletz, Jean-Claude Sardas

\section{To cite this version:}

Olivier Baly, Frédéric Kletz, Jean-Claude Sardas. Collective Sensemaking: The Cave within the Cage. 76th Annual Meeting of the Academy of Management, Aug 2016, Anaheim, United States. hal-01305315

\section{HAL Id: hal-01305315 \\ https://hal-mines-paristech.archives-ouvertes.fr/hal-01305315}

Submitted on 23 Apr 2016

HAL is a multi-disciplinary open access archive for the deposit and dissemination of scientific research documents, whether they are published or not. The documents may come from teaching and research institutions in France or abroad, or from public or private research centers.
L'archive ouverte pluridisciplinaire HAL, est destinée au dépôt et à la diffusion de documents scientifiques de niveau recherche, publiés ou non, émanant des établissements d'enseignement et de recherche français ou étrangers, des laboratoires publics ou privés. 


\title{
Collective Sensemaking: The Cave within the Cage
}

\section{Olivier BALY ${ }^{1}$, Frédéric KLETZ ${ }^{1}$, Jean-Claude SARDAS ${ }^{1}$}

\begin{abstract}
Situated cognition and neo-institutional theory have revived two fruitful allegories of collective sensemaking within organizations: Plato's Simile of the Cave and Max Weber's Iron Cage. Scholarly efforts to combine these two approaches have converged towards a shared vision of collective sensemaking as an interaction between institutionalized cognitive schemas and contextual grounding. Nevertheless, the mechanisms framing and shaping the outcome of this contextual cognitive interaction, i.e. the collective meanings actually produced and institutionalized, have remained largely unexplored. We aim to address this common gap by examining how the interplay of institutional and contextual factors determined the collective sensemaking of an emergent occupational group, namely, management controllers in French hospitals. Comparing the results from a two-year focus group study held in a community of practice and survey data from 163 respondents, we draw consistent findings indicating that a similar position within supervision micro-structures, which we label isothetism, contributed to shaping the group's transactive memory and to framing the institutionalization of its cognitive schemas. We conclude by discussing the implications of isothetism for future research on the meaningfulness of organizations.
\end{abstract}

\section{Keywords:}

Collective sensemaking; situated cognition; neo-institutional theory

\footnotetext{
${ }^{1}$ Mines ParisTech, Centre de Gestion Scientifique
} 


\section{Collective Sensemaking: The Cave within the Cage}

Collective sensemaking can be defined as the process in which "individuals exchange provisional understandings and try to agree on consensual interpretations and a course of action" (Stigliani \& Ravasi, 2012: 1232). Like individual sensemaking, collective sensemaking is prompted by novel and ambiguous situations (Weick, 1995). However, it stems from the above definition that examining sensemaking at the collective level requires questioning how this novelty and this ambiguity are dealt with through social interaction (Weick, Sutcliffe, \& Obstfeld, 2005), and how collective meanings arise from this interaction.

Two streams of research have provided prominent explanations for the crafting of collective meanings within organizations: neo-institutional theory and the study of situated cognition. DiMaggio and Powell's (1983) seminal work on institutional isomorphism used Max Weber's image of the Iron Cage (Weber, 1952) to account for the sociological mechanisms bounding collective rationality. According to these authors, institutions exert pressure to homogenize organizational rationales through political influence and legitimization (coercive process), imitation (mimetic process), and professionalization (normative process). Elaborating on the concept of bounded rationality (March \& Simon, 1958), situated cognition offers a different analytical framework, based on "the interaction of cognitive schemas and organizational contexts" (Lant, 2002). Like in Plato's (2007) Simile of the Cave, organizational actors derive "persistent knowledge structures" (Elsbach, Barr, \& Hargadon, 2005), referred to as schemas, from the context of interaction in which they are positioned. These schemas constitute stable representations of social identities (self-schemas), processes (event schemas) and relationships between key variables (rule schemas) guiding organizational life. Collective situated cognition in organizations therefore takes the form of a “transactive memory" (Wenger, 1987), indicating that occupational groups derive collective meanings from common relational experience. 
The top/down perspective of neo-institutionalism and the bottom/up approach of collective situated cognition seem to have progressively reached a meeting point. On the neoinstitutionalist side, the focus of research has drifted downwards, from the study of how legitimate structures and practices are diffused in society, towards the examination of translation processes (Czarniawska \& Joerges, 1996) through which institutionalized ideas and practices are reinterpreted in situated organizational contexts (Boxenbaum, 2006). Sahlin and Wedlin (2008) have considered translation as an editing endeavor, in which occupational groups can reformulate the meaning and content of circulating prototypes or templates for organizing. On its part, the literature on situated cognition moved upwards by acknowledging that institutions can influence the collective sensemaking mechanisms occurring within organizations. One of the most prominent efforts to link the micro-mechanisms of sensemaking to the institutional macro-level of analysis has been Weber and Glynn's (2006) conception of institutional sensemaking, explaining how institutions frame the cognitive schemas that compose the building blocks of sensemaking. Viewing institutions as more than mere cognitive constraints (Glynn, 2008), institutional sensemaking recognizes the key role played by institutions in affecting occupational sensemaking, but allows room for both contingency and agency in their effects.

The result of these convergent moves is subsequently a circular one: whereas institutional frames may edit the collective sensemaking of occupational groups, these groups may, in turn, re-edit institutional templates through collective sensemaking. Thus, the conjunction of the two approaches may well resemble the chicken or the egg conundrum: how can institutions serve as a substance for collective occupational sensemaking if they are constantly redefined through this interaction? This puzzle reveals a common gap in the two literatures: while much heed has been paid to describing the processes involved in collective sensemaking, the outcome of these processes, i.e. the meanings actually produced and institutionalized, has 
been seldom explored. On the neo-institutionalist side, Boxenbaum and Jonsson (2008) have underlined that the very assumption of isomorphism, although it lies at the core of neoinstitutional theory, has rarely been empirically tested and verified. Similarly, in spite of Elsbach et al's (2005) remarkable analysis of interaction patterns between cognitive schemas and organizational contexts, the contextual features shaping the production of these schemas remain as question marks. Further research is therefore warranted to identify the institutional and contextual factors that influence the collective sensemaking of occupational groups.

We propose to contribute to answering this research question through the study of a collective sensemaking experience by an emergent occupational group: management controllers in French hospitals. Because newcomers are novel by definition, they have raised the interest of researchers working on sensemaking since the early development of this concept (for an example, see: Louis, 1980). Nevertheless, scholarly attention has mainly been focused on their identification (Horton, McClelland, \& Griffin, 2014; Sluss, Ployhart, Cobb, \& Ashforth, 2012). Although these studies provide a better understanding of newcomers' sensemaking at the level of individuals, they give only little information about the contextual and institutional factors impacting the collective sensemaking of newcomers as a group. Following Zilber (2008), we contend that tackling this issue requires analytical tools to describe the contents of occupational meanings. We argue that a recent elaboration of neoinstitutional theory, the institutional logics perspective (Thornton, Ocasio, \& Lounsbury, 2012), may help accommodate this need, since it has proven useful in examining shifts in work meanings by occupational groups (Dunn \& Jones, 2010; Goodrick \& Reay, 2011; Pouthier, Steele, \& Ocasio, 2013). We therefore applied this framework to assess the contents of management controllers' sensmaking in French hospitals.

In accordance with the two above-mentioned allegories, we devised two tests aimed at identifying the institutional and contextual factors determining management controllers' work 
meanings. We labeled them, respectively, the "test of the cage" and the "test of the cave." In order to make explicit the theoretical grounding of these tests, we will develop, in the first section of this paper, the key assumptions that we derived from the neo-institutional and situated cognition theories. We will then describe the methodology used to conduct each test, and present how the results validate or invalidate these hypotheses. We will conclude by discussing how one of our main findings, namely, the impact of a similar position in supervision micro-structures on the group's sensemaking, may contribute to future research on the meaningfulness of organizations.

\section{THEORETICAL GROUNDING AND HYPOTHESES}

\section{The Cage Frames the Cave}

DiMaggio and Powell (1983) identified three mechanisms constraining collective rationality at the societal and organizational levels: coercion, imposed by the state or prominent organizations in a field, imitation, driven by the search for models to cope with uncertainty, and the normative socialization associated with professionalization. These processes, the authors argued, occur within a given organizational field, which they defined as “a recognized area of institutional life" (DiMaggio and Powell, 1983: 148). In their view, fields are characterized by connectedness and structural similarity between organizations that compose them. This definition of institutional fields echoes the concept of institutionalization: Scott (2001: 15, emphasis in original) claimed that "a system of action is said to be institutionalized to the extent that actors in an ongoing relation oriented their action to a common set of normative standards and value patterns". It can be deduced from this perspective that, as a field becomes more institutionalized, connectedness and structural 
similarity between organizations increase, posing a more restrictive cognitive constraint on collective meanings within that field.

Later neo-institutionalist works shaded light on the role played by carriers in the institutionalization of collective meanings. Scott (2001: 48) emphasized that institutions are "composed of cultural-cognitive, normative, and regulative elements that, together with associated activities and resources, provide stability and meaning to social life," and that carriers transport these institutional elements, which Scott (2003: 880) named "institutional pillars", over time and space. Carriers can thus be pictured as the vehicles of institutionalization. Although Scott did not explicitly mention occupational groups as carriers, Sahlin-Andersson and Engwall (2002) pointed out that individuals, or groups of individuals, could play such a role. Subsequently, we infer from these developments that occupational groups can incorporate elements of these institutional pillars, might they be regulative (such as rules, governance systems, or standard operating procedures), normative (like values or job expectations), or cultural-cognitive.

Sensemaking scholars have devoted special attention to cultural-cognitive elements, since they evoke core notions of sensemaking, such as "scripts," "identities," "schemas," or "typifications." Reexamination of these concepts through institutional lenses gave rise to the institutional sensemaking approach. This stream of research aims to go beyond the vision of institutions as cognitive constraints (Glynn, 2008) by exploring how institutions frame these cultural-cognitive elements. In their seminal work on institutional sensemaking, Weber and Glynn (2006) have identified three forms of typification arising from the institutionalization process: typified actors, originating from "institutionalized identities," typified actions, emanating from "institutionalized expectations," and typified situations, proceeding from "institutionalized frames" of interaction. The combination of institutionalized identities and frames determine "roles," conceived as typified "actor-in-situation." Similarly, "scripts," 
emanating from the combination of institutionalized expectations and frames, constitute typified "action-in-situation."

This conception strays from the initial determinism of early institutional theory in acknowledging agency and contingency in the construction of typifications. Following this path, we consider that the coercive, mimetic and normative mechanisms of the Iron Cage frame collective cognitive schemas more than they prescribe them. From this perspective, institutions, like the state or the professions, do not dictate schemas to organizations and individuals situated in the Cave of sensemaking. Institutions rather provide ready-made schemas, which are seized upon by individuals or groups of individuals during their interaction with others. Accordingly, institutions mainly serve as a baseline for collective sensemaking: in the words of Weber and Glynn (2006: 1648), institutions "prime" sensemaking. Institutional sensemaking therefore allows disagreement, debate and competition between individuals and groups over the prevailing schemas to be adopted. The "activities and resources," which Scott (2001: 48) associated with the institutionalization process, may consequently turn into power relations between carriers of different schemas. In this likely struggle over cognitive schemas, individuals or groups endowed with greater power may exert what Weber and Glynn (2006: 1651) called "social policing of action" in the editing of collective meanings. As a result, cognitive pressure may not proceed directly from disembodied institutions, but from human carriers with sufficient resources to foist their schemas upon others.

This disenchantment of the institutional world, in which institutions no longer operate as if by magic but are embedded into material practices and structures (Jones, Boxenbaum, \& Anthony, 2013), may be particularly cruel for incoming groups in highly institutionalized fields. Indeed, as newcomers, they most certainly lack the necessary resources to impose cognitive schemas of their own, and they are bound to be exposed to the prevailing schemas 
carried over by more institutionalized groups in the field. Normative pressure is therefore liable to push towards inter-group imitation, since emergent groups are prone to adopt the schemas forced upon them by more institutionalized professions. The normative and mimetic processes may therefore be intertwined in this frame. Similarly, coercion is bound to affect groups of newcomers more than others, since resisting political pressures from legitimized domination systems like governmental regulation also requires mobilizing tremendous resources (Lawrence, 2008). As a result, we posit two hypotheses regarding the institutional factors framing the outcome of collective sensemaking by emergent occupational groups in highly institutionalized fields:

Hypothesis 1a. The coercive pressure imposed by governmental regulation on emergent occupational groups frames the meanings that these groups ascribe to their work.

Hypothesis 1b. The normative pressure imposed by institutionalized professions on emergent occupational groups forces them to adopt similar meanings in their work.

\section{The Cave Shapes the Cage}

Plato's (2007: 240) description of the Simile of the Cave strikingly resembles Karl Weick's (1995) theory of sensemaking. The seven properties attributed by Karl Weick to sensemaking apply to Plato's prisoners enchained in a cave: 1. Their sensemaking is interwoven with identity building since they construct representations of themselves, and of the others, based on the shadows they perceive on the wall opposite to them; 2 . Their sensemaking is retrospective, for they interpret the passing shadows according to the previous sequences they remember; 3. The prisoners' sensemaking is enactive of their sensible environment, in so far as they create a world of their own by drawing relations between the sounds they hear and the images they see, and they resist alternative truths uttered by their 
released companion when he comes back to them; 4. The prisoners' sensemaking is deeply social as "honor and glory [is] to be won among the prisoners, and prizes for keensightedness for those best able to remember the order of sequence among the passing shadows and so be best able to divine their future appearances" (Plato, 2007: 243); 5. Since the prisoners' sensemaking is grounded on passing shadows of objects and people, it is ongoing by definition; 6. These shadows provide the cues extracted from their environment on which the prisoners focus to make sense of the world; 7. Plausibility drives their sensemaking far more than accuracy, precisely because they do not see, and therefore do not know, what objects and people above them really look like.

Furthermore, we contend that the Simile of the Cave offers a useful allegory to depict the mechanisms of situated collective cognition. Elsbach and her colleagues (2005) emphasized that what distinguishes collective cognition from shared cognition is the emergence, through social interaction, of a collectivist mindset, which relates to the ability of individuals to think as a group. These authors also stressed that collective mindsets arise from socio-dynamic contexts. We argue that Plato's description of the prisoners' behaviors and reactions confirms this statement: their "perception of personal or social identities" (Elsbach et al., 2005: 425), which defines their "self-schemas," is collective, for they exclude from their group their former companion, who no longer shares the group's distinctive attributes after his return from the upper world. Similarly, the prisoners shape their "understanding about how a process is likely to unfold" (Elsbach et al., 2005: 425), or "event schemas," through interaction, as they compete over their predictive ability to foresee the sequences of passing shadows. In the same way, their unanimous rejection of the revealed truth about the real world shows how their "understanding about how key variables are related" (Elsbach et al., 2005: 425), or "rule schemas," are patently collective: when the released prisoner comes back to the group, none of his former companions is ready to accept his account of the causal link between the 
shadows they see and what occurs in the upper world. The cognitive schemas of the prisoners' group therefore rely on their transactive memory. As Wenger (1987: 191) highlighted: the transactive memory is "not traceable to any of the individuals alone, nor can it be found somewhere 'between' individuals. Rather, it is a property of the group." Inasmuch as they abide long enough to acquire some form of stability, these collective cognitive schemas can be considered as enduring "intra-organizational institutions" (Elsbach, 2002). Consequently, viewed from the Cave, institutions originate from the situated creation of a collective mindset.

This perspective is not contradictory, but rather complementary, to institutional sensemaking. In effect, one limit of the institutional sensemaking framework may be its omission to clearly explain how "social policing of action" (Weber \& Glynn, 2006: 1651) edits the collective sensemaking of those submitted to this kind of control, i.e. to account for their collective internalization of the cognitive constraint imposed on them by more powerful actors. Collective situated cognition helps fill this gap by highlighting that socio-dynamic contexts forge and institutionalize a group's cognitive schemas. Elsbach et al. (2005) have underlined that collectivist mindsets are generally produced through interaction between contexts and "rule schemas." Rule schemas correspond to the typified situations of the institutional sensemaking approach. Similarly, Horton, McClelland and Griffin (2014) identified hierarchical position as a key determinant of workers' identification, which indicates that hierarchical position shapes individuals' self-schemas. Sluss, Ployhart, Cobb and Ashforth (2012) specified that, in the case of newcomers, hierarchical position shapes relational identification in so far as newcomers perceive their immediate supervisor as prototypical. This conclusion therefore confirms the importance of typification in the definition of institutionalized identities and occupational roles, as emphasized by Weber and Glynn (2006). As for event schemas, which form institutionalized expectations regarding how professional scripts should unfold, Wrzesniewski, Dutton and Debebe (2003) demonstrated 
that the expectations of others as to how a group should perform its occupational script shape the meanings that this group ascribes to its work. These authors also stressed that this shaping may be affirming or disaffirming, since it may convey a positive or a negative job meaning. These findings from different research settings all single out relational embedment as the engine of collective cognition, and point to hierarchy as the engine's fuel. Subsequently, we formulate the following two hypotheses regarding the contextual factors shaping the outcome of collective sensemaking by emergent occupational groups:

Hypothesis 2a. The hierarchical position of emergent occupational groups' members shapes their cognitive schemas.

Hypothesis $2 b$. The transactive memory of emergent occupational groups institutionalizes the cognitive schemas shaped in hierarchical interaction.

\section{Lights from Above: The Institutional Logics Perspective}

Soon after his ascent from the cave, the released prisoner in Plato's allegory is still too accustomed to darkness to see by daylight, but he is able to behold the stars (Plato, 2007). Some neo-institutionalist scholars seem to have followed the same path, by unveiling the pluralistic nature of institutional life. Drawing on Max Weber's concept of value spheres (Friedland, 2013), Friedland and Alford (1991) claimed that social order is composed of various institutional logics, which were later defined by Thornton and Ocasio (2008: 101) as "the socially constructed, historical patterns of material practices, assumptions, values, beliefs, and rules by which individuals produce and reproduce their material subsistence, organize time and space, and provide meaning to their social reality." Accordingly, institutions convey a plurality of legitimate meanings, derived form institutional orders. Thornton et al. (2012) identified seven institutional orders, forming an interinstitutional 
system at the societal level: Family, Community, Religion, State, Market, Profession, and Corporation $^{2}$. Each of these orders provide a macro institutional logic, that can be translated at the micro level of the individual as well as at the meso levels of fields or of organizations. The likelihood of a multiple translation of these meta-logics at infra-societal levels gave rise to the concept of "constellations of logics" (Goodrick \& Reay, 2011) to designate the combination of meta-logics embedded in a specific individual, field, or organization.

We contend that this framework advances research on the meaningfulness of organizations because it offers an analytical grid to examine the actual content of meanings enacted within an organization or an occupational group. It therefore allows testing the outcome of the institutional processes stemming from the notion of isomorphism: coercion, imitation and normative professionalization. Institutional logics have also proven useful for examining the meanings that occupational groups ascribe to their work, and for explaining shifts in those meanings. For instance, Dunn and Jones (2010) showed how two logics in the healthcare field, care and science, have imbued medical education, and how distinct groups and interests have directed more attention to the care logic over time. In a similar vein, Goodrick and Reay (2011) applied Thornton and Ocasio's (2008) early version of the interinstitutional system to measure the prevalence of each institutional order in the work of pharmacists. More recently, Pouthier et al. (2013) studied how an emergent group in the medical profession, the hospitalists, built their collective identity first by drawing on, and then by retreating from the logic of managed care in the healthcare field.

Accordingly, we chose to use the framework provided by the institutional logics perspective to test our hypotheses regarding the institutional factors guiding the collective sensemaking of another emergent group in the healthcare field: management controllers in

\footnotetext{
${ }^{2}$ Since institutional orders are ideal-types, we signal them by capital letters at the beginning of words; we applied the same rule to the typifications produced by the focus group.
} 
hospitals. However, we supplemented this deductive approach with a more inductive analysis of the contextual factors binding the group's sensemaking, in order to verify the causal links implied by the institutional and contextual processes that we hypothesized.

\section{METHODS}

\section{Research Setting}

In 2005, the French government reformed the legal framework for hospitals' management (French Ministry of Health, 2005). The term "New Governance" (in French: "Nouvelle Gouverance") was coined to designate this more decentralized form of hospitals' governance in which medical departments were endowed with more autonomous decision power (Bérard, 2013). This regulatory change prompted the development of management control systems in French hospitals (Lartigau, 2009; Pépin \& Moisdon, 2010). By contrast with the American managed care logic (Scott, Ruef, Mendel, \& Caronna, 2000), the French "managerial approach in hospitals" (Engel, Kletz, Moisdon, \& Tonneau, 2000: 1), which culminated with the adoption of the "New Governance" frame, was therefore grounded on the political will to involve healthcare professionals in the management of hospitals, which until then had been the exclusive realm of administrative directors (De Pouvourville \& Tedesco, 2003). Rephrased in the concepts of institutional logics, this regulatory change therefore aimed to a shift from the hierarchical and bureaucratic logic of the Corporation towards the logic of the Profession (Thornton et al., 2012).

Associated with this "New Governance" frame, an activity-based payment system for hospitals' stays was progressively implemented from 2004 onwards. The main purpose of this innovative funding system was to set up a new form of regulation based on tariff pricing rather than resource allocation by the state (Lenay, 2005). Increased competition among 
hospitals now responsible for their revenues resulted in a search for cost-efficiency and market-share maximization in both public and private French hospitals (Cazin, 2016; Louazel \& Keller, 2016). Speaking in terms of institutional logics, this financial turn corresponds to a move from the redistributive and administrative logic of the State to the profit-oriented and competitive logic of the Market (Thornton et al., 2012). Analyzing statistical data from the French Ministry of Health, Baly (2015) noticed a surge in the recruitment of management controllers in French hospitals during the ramp-up period of this new payment model.

Management controllers in French hospitals can thus be considered as the carriers of new regulative templates challenging the prevailing logics at play in their organizations. As an emerging occupational group, their lack of existing knowledge and professionalization alerted the French Ministry of Health, which entrusted the French National Agency for Hospitals' Performance with the mission to create a community of practice open to all management controllers working in the field of hospitals. By the time we started our inquiry, this community comprised 71 members representing 49 public and non-profit hospitals of different status, size, and activity, as well as 13 members serving in national agencies or regional healthcare authorities. We seized the opportunity given by the creation of this community to investigate on this emergent occupational group.

This field seemed adequate to test our hypotheses since healthcare is recognized as a highly mature and pluralistic field, in which multiple institutional logics and their carriers have been engaged in an enduring struggle (Greewood, Raynard, Kodeih, Micelotta, \& Lounsbury, 2011; Scott et al., 2000). The constitution of a fresh group of carriers, propelled by new regulative templates challenging the institutional status quo in central organizations of this field (Battilana, 2010), allowed us to analyze the outcome of the institutional and contextual mechanisms that we had identified as the key processes in collective sensemaking by emergent occupational groups. Further more, hospitals offer particularly relevant cases to 
examine the meaningfulness of organizations, for charity lies at the core of their historical foundation (Foucault, 1963). Therefore, the integration of business and governance models imbued with notions of profitability and cost-efficiency in their structure literally mirrors the issue of Corporate Social Responsibility of firms (Glynn \& Raffaelli, 2013) by presenting a reverse dynamic, which threatens to dampen the social meaningfulness of these organizations.

\section{The Test of the Cage}

Data collection. To test our hypotheses regarding the institutional factors framing the outcome of collective sensemaking by emergent occupational groups in highly institutionalized fields (Hypotheses 1a and 1b), we needed to draw the typified representations, as defined by Weber and Glynn (2006), of the group under study. Since focus groups had previously proven to be a valuable research method in order to generate common occupational representations in healthcare settings (Kitzinger, 1995; Liamputtong, 2011), we chose this methodology to capture an image of the group's transactive memory, in a material and narrative form. We therefore asked members of the community who had volunteered to participate in the study to fill in factsheets, in which they had to describe the situations and actors they encountered in their work practice, as well as the actions that these actors, including themselves, performed in those situations. The initial versions of factsheets were produced by sub-group of two to three management controllers in two-hour sessions. These initial versions were then examined in workshops comprising an average of 10 to 12 participants, during which sub-groups presented their factsheets to others. In these three-tofour-hour workshops, factsheets were discussed and modified, until all participants reached a consensus. In order to further reduce the risk of self-report bias, we asked group members to provide examples of tools or documents illustrating the contents of the factsheets in the weeks 
following the workshop sessions. In total, fifteen focus group meetings were held from November 2012 to September 2014, involving 31 professionals from 25 different hospitals, and 5 professionals working in regional healthcare authorities. In addition, the factsheets were debated and supplemented in ten community meetings, to which all community members were invited. Eventually, 14 community members reviewed printed versions of factsheets, bringing final modifications and further materials.

The output of these focus groups was 32 factsheets, totalizing 260 pages. Each factsheet corresponded to a distinct typified situation, as showed in Appendix A. Five typified actors were identified by focus group members: the Management Controller, the Head of Medical Information Department (HMID), the Medical Departments' Management Teams, the Hospital's Directors, and the Supervisory Board. In French hospitals, the HMID is the physician in charge of collecting, controlling, processing and anonymizing all medical information concerning patients' stays. Medical Departments' Management Teams comprise Heads of these Departments, who, according to the "New Governance" frame, must be physicians, Departments' Coordinating Nurses, and sometimes Departments' Administrative Assistants. These Assistants may, in some hospitals, report hierarchically to the Management Controller. As focus group members favored this configuration, we grouped the Assistants, and the actions associated to them, with the Management Controller. Directors form the top executive management of the hospital. Supervisory Board members include representatives of local communities, trade unions and patients. 242 actions were mentioned in factsheets, after actions in factsheets 14 to 28 were pooled, since focus group members deemed them similar. Each action was related to the actor performing them.

Data analysis. In order to identify the "roles" and "scripts" (Weber \& Glynn, 2006: 1644) described by focus group members, we gathered typified actions in a double entry table, placing their associated typified actors in columns, and their associated typified situations in 
lines. Accordingly, a column corresponded to a typified actor's role, whereas a line showed the scripts expected in a typified situation (or group of situations in the case of factsheets 14 to 28). We then coded each of the 242 typified actions using Thornton et al.'s (2012) framework of institutional logics. Following Goodrick and Reay's (2011) methodology, each typified action was coded according to the attributes of institutional logics in Thornton et al.'s interinstitutional system, but in its ultimate version (Thornton et al., 2012: 53). For instance, a typified action implying a cost-efficiency analysis, a search for profit or for market share maximization, was related to the Market logic. In the same way, bureaucratic typified actions embedded in a hierarchical form of control were seen as pertaining to the logic of the Corporation. Typified actions revealing a delegation of responsibilities to health professionals, endowing them with more autonomous decision power, or granting them discretionary resources, were deemed proof of the Professional logic. Typified actions undertaken to comply with instructions from governmental or regional healthcare authorities were categorized in the State logic. Finally, typified actions involving members of the local environment were ascribed to the Community logic. We found no evidence of the Family or the Religious logics in our data set.

Each typified action was coded using a linear numerical evaluation model in which the score of each logic $(y)$ comprised in an typified action was an inverted function of the number of logics $(x)$ implied in that action, the regression coefficient of the equation $(a)$ being the total number of logics at play in the system: 5. For instance, the action "The Management Controller meets Medical Departments' Management Teams to discuss with them the results achieved by their units" was judged as serving both the Corporate and the Professional logics, since it reveals both a bureaucratic form of reporting and the acknowledgement that only health professionals can account for their activity. A purely bureaucratic means of control would indeed not have entailed any kind of discussion with operators over the outcome of 
their work. Similarly, had the professional logic been uniquely prevailing, the results of medical practice would not have been debated with non-physicians. The mere fact that the outcomes of medical practice were analyzed through corporate measurements was in and of itself the result of a merger between the Corporate and the Professional logics. Consequently, since only two logics were involved, the score of $2,5(y=5 / 2)$ was given to each of these logics for this action. Out of the 242 action described in the system, $61 \%$ were deemed monological, in that they referred to one logic only, 32\% bi-logical, and 7\% tri-logical. No action was considered as comprising more than three logics.

In accordance with our analytical framework, the same typified action performed by different typified actors should be coded differently, because it implied a different script. As an example, "Providing data on resources and achievements of Medical Departments for management reviews" does not conjure the same logics when performed by the HMID or by Directors, because these two actors do not process the same kind of data. In this case, the information given by the HMID may include financial data, like the average value of patients' stays in a medical unit, operational indicators, like the average length of stays, and anonymous medical statistics, like the number of biological tests used for a specific pathology. These data therefore embrace a mixture of profit and performance analyses, referring to the Market logic, as well as bona fide medical information that must legally be controlled by the HMID alone, according to a purely Professional logic. Furthermore, transmitting information for management reviews is an act of bureaucratic reporting corresponding to the Corporate logic. As a consequence, each of these three logics was granted a score of $1,67(y=5 / 3)$ for the action as performed by the HMID. Realizing the same action, Directors can only provide data on resources consumed by medical departments, which will be used during management reviews to assess the cost-efficiency of these units. As 
a result, the same action performed by Directors solely implies the Market and the Corporate logics, hence a score of 2,5 for each of them.

Using the scores obtained by each script, i.e. each typified action as performed by each typified actor in each typified situation, we calculated the prevalence of each institutional logic in the role of each actor, and in situational frames as a whole. Our data set was initially coded by one of the authors, who then presented the results of this first round of coding to the other two. After receiving the comments of the other authors, the initial coder proceeded to a second round of coding, systematically reexamining each script, and paying particular attention to any sing of the less prevalent logics. Where coding was deemed questionable by the initial coder, it was discussed and modified by the three authors together. This work lead to the re-coding of 28 scripts, with marginal impact on the final results: the Market and the Professional logics respectively increased by $2.62 \%$ and $0.55 \%$, while the Corporate logic dropped by $3.17 \%$. The overall balance between institutional logics in scripts, roles and frames thus remained unchanged. Furthermore, the regression being linear, our method prevented subjective adjudication of the relative closeness of each script to its referred $\operatorname{logic}(\mathrm{s})$.

Appraising the prevalence institutional logics in situational frames, and in the role of each typified actor, allowed us to test our hypotheses regarding the institutional factors framing the outcome of collective sensemaking by emergent occupational groups in highly institutionalized fields. If our intuition that the coercive pressure imposed by governmental regulation on emergent occupational groups frames the meanings that these groups ascribe to their work (Hypothesis 1a) is true, then the Professional and Market logics, which prevailed in the regulative templates that gave rise to management control systems in French hospitals, should also prevail in the meanings that management controllers' ascribe to their role and to their working situational frames. Similarly, if the proposition that the normative pressure 
imposed by institutionalized professions on emergent occupational groups forces them to adopt similar meanings in their work (Hypothesis $1 b$ ) is true, then a significant level of correlation should be found between the mix of logics in the Management Controller's role and the mix of logics in other typified actors' roles.

\section{The Test of the Cave}

Data collection. Although analyzing the outcome of management controllers' collective sensemaking was important to evaluate the institutional processes framing the meanings they assigned to their work, it did not suffice do draw causal links between their contextual embedment and this outcome. For this reason, we supplemented our focus group study with an on-line survey inquiry in order to test our hypotheses regarding the contextual factors shaping emergent groups' collective sensemaking. We first wanted to verify that management controllers actually were an emergent occupational group by collecting data on their age, number of years in office, past experience in similar positions, academic or vocational background and employment status. Age was measured using a multiple-choice scale ranging from " 18 to 25 years old," " 25 to 35 years old," " 35 to 45 years old," " 45 to 55 years old," to "56 years old and more." Number of years in office scaled from "less than a year," "1 to 2 years," "2 to 5 years," "5 to 10 years," to "more than 10 years." Past experience in a similar position was assessed by dichotomous "yes" or "no" answers to the following question: "Have you held the position of management controller in another hospital before your current job?" Academic or vocational background was also evaluated with "yes" or "no" nonexclusive questions proposing the following options: "hospital civil service internal training," "business school," "university degree in management control," "other university degree," "specialization in hospital management," "engineering school," "School for Public Hospitals' 
Directors," "other academic training." Respondents choosing the latter option were asked to specify their answer. Employment status was appraised through a multiple-choice question offering the following options: "fixed-term contract," "permanent contract," "hospital civil servant - medium level category," "hospital civil servant - upper level category," "other." Similarly, respondents choosing the latter option were asked to specify their answer.

As our main purpose was nevertheless to test the impact of respondents' hierarchical positions on their cognitive schemas, we asked them if they saw "advantages" or "difficulties" in their hierarchical position. Respondents could also specify, by answering an open question, what these advantages or difficulties were. We deliberately used the vague and general terms "advantages" and "difficulties" to avoid confirmation bias inducing only answers related to cognitive schemas. Moreover, these terms allowed for both positive (affirming) and negative (disaffirming) statements. In order to pre-identify the most common hierarchical positions of management controllers in hospitals, we consulted national statics provided by the French National Observatory for Analytical Accountings in Hospitals (NOAAH; in French: "Observatoire National de la Comptabilité Analytique Hospitalière"), run by the French Ministry of Health. These statistics indicated five hierarchical positions for management controllers in hospitals at the end of the year 2012: under the direct supervision of a Finance Director for $69 \%$ of them, under the direct supervision of a Chief Executive Director for $25 \%$ of them, positioned in a Management Control Department in $4 \%$ of cases, positioned in a Department of Performance and/or Quality in less than 1\% of cases, leaving only less than 2\% of "other" cases. We therefore proposed survey respondents to select between these preset categories in a multiple-choice question, although we asked them to specify their choice if they selected the "Other" category. Eventually, since focus group participants had frequently mentioned that their relationship with the HMID was an essential element for the accomplishment of their work, we wanted to gauge the frequency of management controllers' 
interaction with this actor. We therefore asked survey participants if they met with the HMID "at least once a month," "at least every three months," "punctually or when necessary," or "never."

We used the LimeSurvey application to broadcast the survey to all community members, who diffused it to other management controllers they knew. In total, 163 respondents, working as management controllers in hospitals, completed the survey on line, from February to March 2014.

Data analysis. We extracted the survey database in Excel format to facilitate our analysis. We first checked the representativeness of our sample, by comparing the distribution of the five hierarchical positions in our sample population to their national distribution in the NOAAH database. 158 out of 163 respondents answered to the multiple-choice question of their hierarchical position. Pearson's correlation coefficient between the distribution of hierarchical positions in those answers and the national distribution in the NOAAH database was 0.98 , indicating an excellent representativeness of the sample in terms of hierarchical positions. 127 out of these 158 respondents gave meaningful answers openly detailing what they deemed were the advantages and/or difficulties associated with their hierarchical position. Meaningless answers were either empty or too vague to be analyzed (e.g. two respondents just mentioned "position" as a difficulty). One respondent declared that he did not understand the question.

As for the questions regarding respondents' age, number of years in office, past experience in similar positions, academic background, employment status and frequency of interaction with the HMID, we calculated the percentage of each available option in the total of meaningful answers. In order to analyze the advantages and difficulties reported by respondents as regarded their hierarchical position, we used Gioia, Corley and Hamilton's 
(2013) methodology for inductive research. This methodology relies on the progressive categorization and conceptualization of field data collected in the form of textual materials. It distinguishes between $1^{\text {st }}$ order categories, which consist of coherent groups of informants' verbatim, $2^{\text {nd }}$ order themes, which are field constructs based on the analysis of the similarities and differences between $1^{\text {st }}$ order categories, and aggregate dimensions, which are theoretical concepts derived either from induction or from extant concepts in the literature. We chose this methodology because it allows a rigorous examination of field data, following a data structure presenting the relations between each level of categorization. Accordingly, we considered the answers given by respondents in each of the five hierarchical positions as $1^{\text {st }}$ order categories. We then looked for similarities and differences between the words used by respondents to construct $2^{\text {nd }}$ order themes. At this level, we tried to identify the most recurrent phrases in respondents' answers and we used them to define $2^{\text {nd }}$ order themes, thereby retaining informants' terms. We created a $2^{\text {nd }}$ order theme whenever a $1^{\text {st }}$ order term did not match a previous $2^{\text {nd }}$ order theme, or whenever a $1^{\text {st }}$ order term encompassed several previous $2^{\text {nd }}$ themes. In the latter cases, we grouped all the answers categorized in the previous $2^{\text {nd }}$ order themes into the new one. Finally, we aggregated $2^{\text {nd }}$ order themes in accordance with the theoretical concepts that we used to formulate Hypotheses $2 \mathrm{a}$ and $2 \mathrm{~b}$. We therefore examined whether each $2^{\text {nd }}$ order theme revealed a shaping of one of the cognitive schemas identified by Elsbach et al. (2005), to wit: rule, event or self-schemas. Subsequently, we were able to determine if hierarchical position shapes these three cognitive schemas (Hypothesis 2a). The comparison of these results with those of the focus group study allowed us to evaluate the institutionalization of these cognitive schemas, by analyzing whether there remains a "transactive memory" of these hierarchical interactions (Hypothesis 2b) in the balance of institutional logics emanating from the group's collective sensemaking. 


\section{RESULTS}

\section{Emergent Groups of Carriers Can Reframe their Constitutive Regulatory Templates}

Survey data confirm that management controllers in French hospitals constitute an emergent occupational group, who has arisen in the decade following the implementation of the "New Governance" template and the activity-based payment model (2004-2014). 77\% of the 163 respondents in our sample had been in office for less than ten years at the beginning of the year 2014 , and only $18 \%$ of the latter had held a similar position in another hospital before. Therefore, for $59 \%$ of respondents, their current position was their first work experience as a management controller in a hospital, and they had been recruited during the past decade. Accordingly, $73 \%$ of the sample was below 45 years old, and $42 \%$ of it was below 35 years old. Although $59 \%$ of the sample enjoyed a permanent contract, only $25 \%$ of respondents were civil servants, indicating that the most frequent employment status among the group diverged from the tenure system common in the French public hospitals' administration. Logically, only $23 \%$ of the total sample had followed a specialized professional or academic training in hospital management. The bulk of respondents hold a university degree in management control (31\%) or a business school degree $(21 \%) .25 \%$ of respondents hold another university degree (most of the time in accountings) and $2 \%$ of them were engineers ${ }^{3}$. Therefore, the academic or vocational background of respondents was mostly exterior to the healthcare field, showing a functional rather than a sector-specific specialization.

With such a background, management controllers could be expected to fit in the Market logic promoted by the activity-based payment model, which propelled their recruitment in

\footnotetext{
${ }^{3}$ As the questions related to academic or vocation background were not exclusive, the total of percentages exceeds $100 \%$.
} 
hospitals. Similarly, since most of them started working in hospitals after the implementation of the "New Governance" frame, they should be familiar with the Professional logic of physicians and nurses in their every-day situational frames. In effect, the first nine factsheets showed in Appendix A are directly related to this new frame of governance, and the fourteen following factsheets deal with the production of the two main management tools for medical departments: scoreboards and analytical income statements. However, the results of our prevalence analysis of institutional logics in the focus group's typifications, presented in Table 1, contradict these presumptions: the dominant logic in the Management Controller's role is by far the Corporate logic, permeating $61 \%$ of the scripts that focus group participants have associated to their role; the Corporate logic also imbues $54.61 \%$ of total situational frames, which places it as the prevailing institutional logic in the focus group's collective sensemaking. The Market and Professional logics respectively determine only $21 \%$ and $18 \%$ of the Management Controller's role, as well as $20.11 \%$ and $23.83 \%$ of total situational frames. The State and Community logics are not represented in the Management Controller's role, and they only permeate, respectively, $1.03 \%$ and $0.41 \%$ of total situational frames.

Insert Table 1 about here

These results invalidate Hypothesis 1a, which stated that the coercive pressure imposed by governmental regulation on emergent occupational groups frames the meanings that these groups ascribe to their work, since management controllers in hospitals, although they clearly form an emergent occupational group in the healthcare field, do not primarily refer to the institutional logics prevailing in their constitutive regulative templates. We therefore have to identify the contextual features that could explain how this group ended up reframing the meaning of the regulative template they were meant to carry. 


\section{Hierarchical Position Shapes the Cognitive Schemas of Emergent Occupational Groups}

Our examination of the "advantages" and "difficulties" reported by survey participants as regarded their hierarchical position validate Hypothesis $2 \mathrm{a}$ asserting that the hierarchical position of emergent occupational groups' members shapes their cognitive schemas. The inductive analysis conducted on the 127 open answers reporting advantages and difficulties confirms that hierarchical position shapes the three cognitive schemas described by Elsbach et al. (2005), i.e. self-schemas, rule schemas, and event schemas. Furthermore, the use of Gioia et al.'s (2013) methodology allows the identification of the $2^{\text {nd }}$ order themes, as well as the type of supervision (categorized in $1^{\text {st }}$ order answers), that most contribute to the shaping of each cognitive schema. $73 \%$ of the 158 respondents who indicated their hierarchical position were under the direct supervision of a Finance Director, 15\% of them were under the direct supervision of a Chief Executive Director, 5\% of them were positioned in a Management Control Department, 3\% of them were positioned in a Department of Performance and/or Quality, and 4\% of them occupied "other" positions. As shown in Table 2, in the total of 127 meaningful answers describing difficulties or advantages, we found 26 instances of references to self-schemas, 104 to rule schemas, and 77 to event schemas, considering that a single answer could point to several schemas. In total, the shaping of these schemas is more positive than negative, since $70 \%$ of instances indicate a positive framing, affirming the respondent's desired schemas, and only 30\% reveal a negative framing, disaffirming the respondent's desired schemas.

Insert Table 2 about here 
In accordance with the distribution of hierarchical positions among respondents, which is representative of the total population of French management controllers in hospitals, the supervision of the Finance Director is related to the $2^{\text {nd }}$ order themes that most contribute to the shaping of the group's three cognitive schemas, followed by the supervision of the Chief Executive Director. Self-schemas are mainly shaped negatively (at 54\%) through assimilation. This means that $54 \%$ of the instances referring to self-schemas indicated that the respondents were assimilated to the Finance Director's team and that this assimilation was contrary to their desired self-schema. Nonetheless, $42 \%$ of the instances associated with self-schemas report a positive framing of identity, fueled by a feeling of closeness with the respondent's supervisor. By contrast with self-schemas, rule schemas are mostly shaped affirmatively, at $53 \%$ through a smooth information process with the respondents' supervisor, who was the Finance Director in $91 \%$ of these instances and the Chief Executive Director in the remaining $9 \%$ of cases. This signifies that $53 \%$ of instances pointing to rule schemas reveal that the respondents positively valued the smooth information process with their supervisor, who was a Director. This relation with their supervisor was therefore consistent with their desired rule schema. Similarly, event schemas are positively shaped, at $70 \%$ by enhanced collaboration with the respondents' supervisor, who, in $96 \%$ of these instances, was a Finance Director. This finding signals that for $70 \%$ of respondents who evoked event schemas, enhanced collaboration with their supervisor, who was at $96 \%$ a Finance Director, complied with their desired event schema.

\section{Transactive Memory Frames the Institutionalization of Newcomers' Cognitive Schemas}

The effect of this hierarchical cognitive shaping on management controllers' transactive memory is demonstrated by the correlation coefficient between the role of the Management 
Controller and the role of Directors $(r=0.97)$ presented in Table 1. This strong role correlation between the Management Controller and Directors indicates that the transactive memory of focus group participants attributed similar scripts, in terms of institutional logics, to them and to the most frequent supervisor of their occupational group. This result supports Hypothesis $2 \mathrm{~b}$, which stipulates that the transactive memory of emergent occupational groups institutionalizes the cognitive schemas shaped in hierarchical interaction, since the analysis of management controllers' transactive memory shows collective cognitive schemas that are institutionally consistent with those of the group's main supervisors.

The similarity of institutional roles and scripts between the Management Controller and Directors signals that focus group participants associated the same normative standards to them and to their occupational group's most frequent supervisors. This finding therefore confirms Hypothesis $1 \mathrm{~b}$, which posits that the normative pressure imposed by institutionalized professions on emergent occupational groups forces them to adopt similar meanings in their work, but refines this hypothesis by highlighting that normative pressure is exerted through supervision. In effect, although Medical Departments' Teams also encompass highly institutionalized professions in the healthcare field, like physicians and nurses, management controllers are not under their supervision. Accordingly, focus group participants did not perceive themselves as sharing their normative standards, hence a non-significant role correlation $(r=0.32)$.

As for the role correlation observed between the Management Controller and the HMID ( $r$ $=0.84$ ), survey data about the frequency of interaction between management controllers and HMIDs did not produce a satisfactory explanation, since half of the 163 respondents declared that they met the HMID of their hospital less than once a month. Consequently, no causal link can be drawn between this relatively low frequency of interaction and the good role correlation between these actors $(r=0.84)$. Nevertheless, this result does not invalidate 
Hypotheses $1 b$ and $2 b$, since this role correlation is significantly lower than the one observed with Directors.

As a whole, our results converge towards the identification of one contextual factor shaping the collective sensemaking of management controllers in French hospitals and framing the mechanisms of their institutionalization: the similar position of group members in hierarchical structures of supervision. Supervision shapes the cognitive schemas incrusted in the transactive memory of the group. The persistence of this memory institutionalizes these cognitive schemas, as newcomers adopt their supervisors' mix of institutional logics. Imitation and normative pressure are therefore grounded on supervision. Supervision appears as a stronger mechanism than coercion, since it may reframe the regulative templates that emergent occupational groups carry. Supervision structures embedded in organizations therefore seem to prevail over macro state regulation. Occupational groups' similarity of position within supervision micro-structures may subsequently provide an answer to the research question formulated in our introduction, concerning the institutional and contextual factors influencing the collective sensemaking of occupational groups.

\section{DISCUSSION}

\section{The Panoptical Effect of Hierarchical Supervision on Collective Sensemaking}

These findings reflect Foucault's (1977) description of power/knowledge relations, based on his analysis of Bentham's Panopticon. According to Foucault, Bentham's Panopticon symbolizes "discipline" (Foucault, 1977: 161), which Foucault defines as a form of social control relying on supervision structures. In the Panopticon, prisoners are isolated into individual cells, which give onto a tower through open windows. Whereas supervisors placed in the tower can oversee all the prisoners, prisoners are not able to discern whether 
supervisors are actually watching them or not. The principle of this control system therefore lies in prisoners' internalization of discipline: as they can never know whether they are watched upon or not, they have to constantly abide by the rules of the prison and behave accordingly. In this automated form of power, grounded on an architectural construction imposing a similar position to the supervised, prisoners "become the principle of [their] own subjection" (Foucault, 1977: 236). Our study demonstrate the relevance of this theory for emergent occupational groups, since a similar position in hierarchical supervision structures, which we label isothetism, has shaped the cognitive schemas of French hospitals' management controllers, to the point that this group has internalized, in its transactive memory, the effects of this supervision. By stressing the internalization of supervision, we do not pretend that group members are consciously afraid of being observed and sanctioned if they deviate. We simply indicate that the "homogenous effects of power" (Foucault, 1977: 236) produced by supervision are still salient in the groups' transactive memory, and that these effects frames the "cultural-cognitive, normative, and regulative elements" (Scott, 2001: 48) that constitute the institutional pillars on which the group's collective sensemaking rests. Subsequently, hierarchical isothetism influences the outcome of the isomorphic institutional processes identified by DiMaggio and Powell (1983): regulative templates imposed by legal coercion may be redefined, and normative imitation occurs between newcomers and their supervisors.

The notion of isothetism may therefore contribute to a better understanding of the underlying mechanisms of institutional change and maintenance (Lawrence, 2008) and of the persistence of situated cognitive cognition. As we noted in our introduction, the combination of the convergent developments in the theories of collective situated cognition and of institutional sensemaking leads to a paradoxical conclusion questioning the mere possibility of institutional maintenance, since collective sensemaking simultaneously appears as enactive 
of and enacted by and institutions. This paradox stems from a common gap in both approaches: the dearth of research on the power structures that maintain institutions (as attested by Lawrence, 2008) and shape sensemaking (as pointed out by Weick et al., 2005). We contend that the study of isothetism may bridge this common gap by unveiling how the position of different carriers of institutional logics in supervision micro-structures may result in the maintenance or in the modification of the institutional status quo prevailing within a field or an organization. As Elsbach et al.'s (2005: 430) emphasized, "situated cognitions in organizations are transitory or temporally bounded outcomes." Thus, exploring the factors explaining their persistence over time is necessary in both literatures. Future research is subsequently warranted in order to test how variation in the organizational design of supervision structures influences institutionalized cognitive schemas and impacts the meaningfulness of organizations.

\section{Implication of Isothetism for Future Research on the Meaningfulness of Organizations}

Our study confirms Thornton et al.'s (2012: 2) assertion that “institutional logics represent frames of reference that condition actors' choices for sense-making" but supplements it by adding that a similar position in supervision micro-structures embedded within organizations may shape these choices at group level. Since institutional logics inform "the socially constructed, historical patterns of material practices, assumptions, values, beliefs, and rules by which individuals (...) provide meaning to their social reality" (Thornton and Ocasio, 2008: 101), institutional logics constitute the building blocks of social meaning-making. As illustrated by Glynn and Raffaelli (2013) in their examination of Corporate Social Responsibility (CSR), this meaning-making process is structurally embedded in organizations, in so far as organizations tend to place practices carrying different institutional 
logics into distinct units. This structural hybridity (Greenwood et al., 2011) is particularly salient in management controllers' description of hospitals, for they perceive top management as mostly driven by the Corporate logic, whereas they see the Professional logic prevailing in medical departments. This picture of hospitals from the newcomers' point of view portrays a battlefield between carriers of antagonistic institutional logics. Our study demonstrates that the position of newcomers under the supervision of a camp or another will determine their work meaning, subsequently bringing new troops on one side. As a whole, the overall meaning of the organization, if there is one, will ever result from a temporary settlement between these carriers engaged in power relations.

Our analysis of newcomers' isothetism in hospitals therefore provides new insights for the research on the meaningfulness of organizations by presenting a reverse case in comparison with CSR: whereas the notion of CSR aims to challenge the dominance of the Market logic in firms (Glynn \& Raffaelli, 2013), the implementation of management control in French hospitals was an attempt to increase this logic in these organizations. The failure of this regulative "institutional entrepreneurship" (Battilana, Leca and Boxenbaum, 2009) does not imply that such an endeavor cannot be successful. On the contrary, isothetism suggests that in order to change the balance of institutional logics within organizations, the position of new logic carriers in the supervision structures embedded in those organizations should be attended to. This proposition is consistent with recent works in the field of social enterprises, which highlight the role of organizational design in the combination of charity and business logics (Battilana and Lee, 2014). As research in this domain is still nascent, we argue that further examination of the practical implications of newcomers' isothetism on meaningmaking processes in organizations could contribute to a better understanding of how organizations become socially meaningful. In that respect, configurational comparative methods (Rihoux and Ragin, 2009) could be helpful in evaluating how different 
configurations of supervision structures, involving carriers of various institutional logics, lead to distinct outcomes in terms of social meaningfulness of organizations. We are confident that the study of intra-organizational isothetism could thus nurture the growing awareness of social issues in neo-institutional scholarship (Nilsson, 2015).

\section{Conclusion}

The motto "Let no one ignorant of geometry enter here" was supposedly engraved on the pediment of Plato's Academia. Without calling for such exclusiveness, we believe that a little more geometry could be useful for the analysis of organizational meaningfulness. By highlighting the cognitive effects of hierarchical isothetism among management controllers in French hospitals, we hope that our study will help provide a more comprehensive view of the mechanisms shaping and framing the collective sensemaking of emergent occupational groups, and open new avenues for future research on the contextual and institutional factors determining the outcome of meaning production in organizational contexts.

\section{REFERENCES}

Baly, O. 2015. Le contrôle de gestion hospitalier: une innovation managériale dans le pilotage des établissements de santé? In B. Fermon, \& P. Grandjean (Eds.), Performance et innovation dans les établissements de santé: 409-432. Paris: Dunod.

Battilana, J., Leca, B., \& Boxenbaum, E. 2009. How actors change institutions: Towards a theory of institutional entrepreneurship. Academy of Management Annals, 3: 65-107.

Battilana, J. 2010. The enabling role of social position in diverging from the institutional status quo: Evidence from the UK National Health Service. Organization Science, 22(4): 817-834.

Battilana, J., \& Lee, M. 2014. Advancing Research on Hybrid Organizing-Insights from the Study of Social Enterprises. Academy of Management Annals, 8: 397-441. 
Bérard, E. 2013. Les pôles d'activité à l'hôpital vus comme un système cybernétique: une analyse en termes de contrôle de gestion. Journal de gestion et d'économie médicales, 31 : 187-205.

Boxenbaum, E. 2006. Lost in translation. The making of Danish diversity management. American Behavioral Scientist, 49: 939-948.

Boxenbaum, E., \& Jonsson, S. 2008. Isomorphism, diffusion and decoupling. In R. Greenwood, C. Oliver, K. Sahlin, \& R. Suddaby (Eds.), The Sage handbook of organizational institutionalism: 78-98. London: Sage.

Cazin, L. 2016. Coopérations territoriales : un nouvel outil stratégique au service de l'hôpitalentreprise? In O. Baly, L. Cazin, J. Despatin, F. Kletz, \& E. Periac (Eds.), Management hospitalier et territoires : les nouveaux défis. Paris: Les Presses des Mines (forthcoming).

Czarniawska, B., \& Joerges, B. 1996. Travels of ideas. In B. Czarniawska \& G. Sevón (Eds.), Translating organizational change: 13-47. Berlin: Walter de Gruyter.

De Pouvourville, G., \& Tedesco, J. 2003. La contractualisation interne dans les établissements hospitaliers publics. Revue française de gestion, 146: 205-218.

DiMaggio, P. J., \& Powell, W. W. 1983. The iron cage revisited: Institutional isomorphism and collective rationality in organizational fields. American Sociological Review, 48: 147160 .

Dunn, M. B., \& Jones, C. 2010. Institutional logics and institutional pluralism: The contestation of care and science logics in medical education, 1967-2005. Administrative Science Quarterly, 55 : 114-149.

Elsbach, K. D. 2002. Intraorganizational institutions. In J. A. C. Baum (Ed.), Companion to Organizations: $37-57$. Oxford: Blackwell Publishers.

Elsbach, K. D., Barr, P. S., \& Hargadon, A. B. 2005. Identifying situated cognition in organizations. Organization Science, 16 (4): 422-433.

Engel, F., Kletz, F., Moisdon, J. C., \& Tonneau, D. 2000. La démarche gestionnaire à l'hôpital, tome 2 : la régulation du système hospitalier. Paris: Seli Arslan.

Foucault, M. 1963. Naissance de la clinique. Paris: Presses Universitaires de France.

Foucault, M. 1977. Surveiller et punir. Paris: Gallimard.

French Ministry of Health. 2005. Ordonnance $\mathrm{n}^{\circ}$ 2005-406 du 2 mai 2005 simplifiant le régime juridique des établissements de santé. Journal Officiel de la République Française, May $3^{\text {rd }} 2005$ (15): 7628-7632.

Friedland, R., \& Alford, R. R. 1991. Bringing society back in symbols, practices, and institutional contradictions. In W. W. Powell \& P. J. DiMaggio (Eds.), The new institutionalismin organizational analysis: 232-263. Chicago: University of Chicago Press.

Friedland, R. 2013. God, love, and other good reasons for practice: Thinking through institutional logics. In M. Lounsbury \& E. Boxenbaum (Eds.), Institutional logics in action: Research in the Sociology of Organizations, vol. 39a: 25-50. Bingley, United Kingdom: Emerald. 
Gioia, D. A., Corley, K. G., \& Hamilton, A. L. 2013. Seeking qualitative rigor in inductive research: Notes on the Gioia methodology. Organizational Research Methods, 00(0): 117.

Glynn, M. A. 2008. Beyond constraint: How institutions enable identities. In R. Greenwood, C. Oliver, K. Sahlin, \& R. Suddaby (Eds.), The Sage handbook of organizational institutionalism: 413-430. London: Sage.

Glynn, M. A., \& Raffaelli, R. 2013. Logic Pluralism, Organizational Design, and Practice Adoption: The Structural Embeddedness of CSR Programs. In M. Lounsbury \& E. Boxenbaum (Eds.), Institutional logics in action: Research in the Sociology of Organizations, vol. 39a: 175-197. Bingley, United Kingdom: Emerald.

Goodrick, E., \& Reay, T. 2011. Constellations of institutional logics: Changes in the professional work of pharmacists. Work and Occupations, 38 (3): 372-416.

Greenwood, R., Raynard, M., Kodeih, F., Micelotta, E., \& Lounsbury, M. 2011. Institutional complexity and organizational responses. Academy of Management Annals, 5: 317-371.

Horton, K. E., McClelland, C. R., \& Griffin M. A. 2014. Defined by our hierarchy? How hierarchical positions shape our identifications and well-being at work. Human Relations, 67: 1167-1188.

Jones, C. Boxenbaum, E., \& Anthony, C. 2013. The immateriality of material practices in institutional logics. In M. Lounsbury \& E. Boxenbaum (Eds.), Institutional logics in action: Research in the Sociology of Organizations, vol. 39a: 51-75. Bingley, United Kingdom: Emerald.

Kitzinger, J. 1995. Qualitative Research: Introducing Focus Group. British Medical Journal, 311: 299-302.

Lant, T. 2002. Organizational cognition and interpretation. In J. A. C. Baum (Ed.), Companion to Organizations: $344-362$. Oxford: Blackwell Publishers.

Lartigau, J. 2009. L'évolution de la fonction contrôle de gestion à l'hôpital. Journal de gestion et d'économie médicales, 27: 371-991.

Lawrence, T. B. 2008. Power, institutions and organizations. In R. Greenwood, C. Oliver, K. Sahlin, \& R. Suddaby (Eds.), The Sage handbook of organizational institutionalism: 170197. London: Sage.

Lenay, O. 2005. L'ergonomie de la gouvernementalité: Le cas du système hospitalier français. In A. Hatchuel, E. Pezet, K. Starkey, \& O. Lenay (Eds.), Gouvernement, organisation et gestion: L'héritage de Michel Foucault: 395-430. Québec: Presses de l'Université Laval.

Liamputtong, P. 2011. Focus Group Methodology: Principle and Practice. London: Sage.

Louazel, M., \& Keller, C. 2016. Entre concurrence et coopération: un "effet bloc" des incitations réglementaires sur les relations entre établissements de santé? In O. Baly, L. Cazin, J. Despatin, F. Kletz, \& E. Periac (Eds.), Management hospitalier et territoires : les nouveaux défis. Paris: Les Presses des Mines (forthcoming).

Louis, M. 1980. Surprise and sensemaking: What newcomers experience in entering unfamiliar organizational settings. Administrative Science Quarterly, 25: 226-251.

March, J. G., \& Simon, H. A. 1958. Organizations. New York: Wiley. 
Nilsson, W. 2015. Positive institutional work: Exploring institutional work through the lens of positive organizational scholarship. Academy of Management Review, 40: 370-398.

Pépin M., \& Moisdon J. C. 2010. Les impacts de la T2A sur les modes d'organisation et de fonctionnement des établissements de santé. Dossiers Solidarité et Santé, DREES, 16: 124.

Plato. 2007. The Republic. London: Penguin Classics.

Pouthier, V., Steele, C., \& Ocasio, W. 2013. From agents to principles: The changing relationship between hospitalist identity and logics of health care. In M. Lounsbury \& E. Boxenbaum (Eds.), Institutional logics in action: Research in the Sociology of Organizations, vol. 39a: 203-241. Bingley, United Kingdom: Emerald.

Rihoux, B, \& Ragin, C. C. 2009. Configurational comparative methods. Applied social research methods series, vol. 51. Thousand Oaks, CA: Sage.

Sahlin-Andersson, K., \& Engwall, L. 2002. The expansion of management knowledge. Carriers, flows and sources. Standford, CA: Standford University Press.

Sahlin, K., \& Wedlin, L. 2008. Circulating ideas: Translation and editing. In R. Greenwood, C. Oliver, K. Sahlin, \& R. Suddaby (Eds.), The Sage handbook of organizational institutionalism: 218-242. London: Sage.

Scott, W. R., Ruef, M., Mendel, P. J., \& Caronna, C. A. 2000. Institutional change and healthcare organizations: From professional dominance to managed care. Chicago: University of Chicago Press.

Scott, W. R. 2001. Institutions and organizations (2nd ed.). Thousand Oaks, CA: Sage.

Scott, W. R. 2003. Institutional carriers: reviewing modes of transporting ideas over time and space and considering their consequences. Industrial and Corporate Change, 12: 879-894.

Sluss, D. M., Ployhart, R. E., Cobb, M. G., \& Ashforth, B. E. 2012. Generalizing newcomers' relational and organizational identifications: Processes and prototypicality. Academy of Management Journal, 55: 949-975.

Stigliani, I, \& Ravasi, D. 2012. Organizing thoughts and connecting brains: Material practices and the transition from individual to group-level prospective sensemaking. Academy of Management Journal, 55: 1232-1259.

Thornton, P. H., \& Ocasio, W. 2008. Institutional logics. In R. Greenwood, C. Oliver, K. Sahlin, \& R. Suddaby (Eds.), The Sage handbook of organizational institutionalism: 99129. London: Sage.

Thornton, P. H., Ocasio, W., \& Lounsbury, M. 2012. The institutional logics perspective. Oxford: Oxford University Press.

Weber, K., \& Glynn, M. A. 2006. Making sense with institutions: context, thought and action in Karl Weick's theory. Organization Studies, 27: 1639-1660.

Weber, M. 1952. The protestant ethic and the spirit of capitalism. New York: Scribner.

Weick, K. E. 1995. Sensemaking in Organizations. Thousand Oaks, CA: Sage.

Weick, K. E., Sutcliffe, K. M., \& Obstfeld, D. 2005. Organizing and the process of sensemaking. Organization Science, 16 (4): 409-421. 
Wenger, D. M. 1987. Transactive memory: A contemporary analysis of the group mind. In B. Mullen \& G. R. Goethals (Eds.), Theories of Group Behavior: 185-208. New York: Springer-Verlag.

Wrzesniewski, A., Dutton, J. E., \& Debebe, G. 2003. Interpersonal sensemaking and the meaning of work. Research in Organizational Behavior, 25: 93-135.

Zilber, T. B. 2008. The work of meanings in institutional processes and thinking. In R. Greenwood, C. Oliver, K. Sahlin, \& R. Suddaby (Eds.), The Sage handbook of organizational institutionalism: 151-169. London: Sage. 
TABLE 1

Prevalence of Institutional Logics in Management Controllers' Typifications

\begin{tabular}{|c|c|c|c|c|c|c|c|}
\hline Roles & $\begin{array}{l}\text { Number } \\
\text { of scripts } \\
\text { per role }\end{array}$ & $\begin{array}{l}\text { Market } \\
\text { logic }\end{array}$ & $\begin{array}{l}\text { Corporate } \\
\text { logic }\end{array}$ & $\begin{array}{c}\text { Professional } \\
\text { logic }\end{array}$ & State logic & $\begin{array}{c}\text { Community } \\
\text { logic }\end{array}$ & $\begin{array}{c}\text { Pearson's } \\
\text { Correlation } \\
\text { Coefficient }(r)\end{array}$ \\
\hline $\begin{array}{l}\text { Management } \\
\text { Controller and } \\
\text { associated } \\
\text { Medical } \\
\text { Departments' } \\
\text { Assistants } \\
\end{array}$ & 63 & $21 \%$ & $61 \%$ & $18 \%$ & $0 \%$ & $0 \%$ & 1 \\
\hline $\begin{array}{l}\text { Head of Medical } \\
\text { Information } \\
\text { Department }\end{array}$ & 27 & $36 \%$ & $40 \%$ & $25 \%$ & $0 \%$ & $0 \%$ & 0.84 \\
\hline $\begin{array}{l}\text { Medical } \\
\text { Departments' } \\
\text { Teams (Head and } \\
\text { Coordinating } \\
\text { Nurse) }\end{array}$ & 54 & $13 \%$ & $23 \%$ & $63 \%$ & $0 \%$ & $0 \%$ & 0.32 \\
\hline Directors & 97 & $19 \%$ & $72 \%$ & $6 \%$ & $3 \%$ & $0 \%$ & 0.97 \\
\hline $\begin{array}{l}\text { Supervisory } \\
\text { Board }\end{array}$ & 1 & $0 \%$ & $0 \%$ & $0 \%$ & $0 \%$ & $100 \%$ & -0.45 \\
\hline $\begin{array}{l}\text { Prevalence of } \\
\text { each logic in total } \\
\text { situational } \\
\text { frames }\end{array}$ & & $20.11 \%$ & $54.61 \%$ & $23.83 \%$ & $1.03 \%$ & $0.41 \%$ & \\
\hline
\end{tabular}


TABLE 2

\section{Affirming and Disaffirming Shaping of Management Controllers' Cognitive Schemas}

\begin{tabular}{|c|c|c|c|c|c|c|c|c|}
\hline \multicolumn{4}{|c|}{ Affirming Shaping } & \multirow{2}{*}{$\begin{array}{c}\text { Aggregate } \\
\text { Dimensions }\end{array}$} & \multicolumn{4}{|c|}{ Disaffirming Shaping } \\
\hline $\begin{array}{l}\text { 1st Order } \\
\text { Category }\end{array}$ & $C . *$ & \begin{tabular}{|c|}
$\begin{array}{c}\text { 2nd Order } \\
\text { Themes }\end{array}$ \\
\end{tabular} & C. $* *$ & & C. ** & $\begin{array}{c}\text { 2nd Order } \\
\text { Themes }\end{array}$ & $C . *$ & $\begin{array}{c}\text { 1st Order } \\
\text { Category }\end{array}$ \\
\hline \multirow[b]{2}{*}{$\begin{array}{l}\text { Supervision of } \\
\text { Finance Director }\end{array}$} & \multirow[b]{2}{*}{$100 \%$} & \multirow[b]{2}{*}{ Closeness } & \multirow[b]{2}{*}{$42 \%$} & \multirow{2}{*}{$\begin{array}{l}\text { Shaping of } \\
\text { Self- } \\
\text { Schemas }\end{array}$} & $54 \%$ & Assimilation & $100 \%$ & $\begin{array}{c}\text { Supervision of } \\
\text { Finance Director }\end{array}$ \\
\hline & & & & & $4 \%$ & Dependence & $100 \%$ & $\begin{array}{c}\text { Supervision of } \\
\text { Chief Executive } \\
\text { Director } \\
\end{array}$ \\
\hline $\begin{array}{c}\text { Number of } \\
\text { instances }\end{array}$ & & 11 & $42 \%$ & 26 & $58 \%$ & 15 & & Number of instances \\
\hline $\begin{array}{l}\text { Supervision of } \\
\text { Finance Director }\end{array}$ & $91 \%$ & \multirow{2}{*}{$\begin{array}{c}\text { Smooth } \\
\text { Information } \\
\text { Processing }\end{array}$} & \multirow[b]{2}{*}{$53 \%$} & \multirow{9}{*}{$\begin{array}{l}\text { Shaping of } \\
\text { Rule } \\
\text { Schemas }\end{array}$} & \multirow[b]{2}{*}{$3 \%$} & \multirow{2}{*}{$\begin{array}{l}\text { Hindered } \\
\text { Information } \\
\text { Process }\end{array}$} & \multirow[b]{2}{*}{$100 \%$} & \multirow{2}{*}{$\begin{array}{l}\text { Supervision of } \\
\text { Chief Executive } \\
\text { Director }\end{array}$} \\
\hline $\begin{array}{c}\text { Supervision of } \\
\text { Chief Executive } \\
\text { Director } \\
\end{array}$ & $9 \%$ & & & & & & & \\
\hline $\begin{array}{c}\text { Supervision of } \\
\text { Finance Director }\end{array}$ & $67 \%$ & \multirow{3}{*}{ Independence } & \multirow{3}{*}{$9 \%$} & & & & & \\
\hline $\begin{array}{c}\text { Supervision of } \\
\text { Chief Executive } \\
\text { Director }\end{array}$ & $11 \%$ & & & & $2 \%$ & Independence & $100 \%$ & $\begin{array}{l}\text { Supervision of } \\
\text { Finance Director }\end{array}$ \\
\hline $\begin{array}{l}\text { Positioned in a } \\
\text { Department of } \\
\text { Management } \\
\text { Control }\end{array}$ & $22 \%$ & & & & & & & \\
\hline $\begin{array}{c}\text { Supervision of } \\
\text { Chief Executive } \\
\text { Director }\end{array}$ & $86 \%$ & \multirow{2}{*}{ Legitimacy } & \multirow{2}{*}{$7 \%$} & & \multirow{2}{*}{$11 \%$} & \multirow{2}{*}{$\begin{array}{c}\text { Lack of } \\
\text { Legitimacy }\end{array}$} & \multirow{2}{*}{$100 \%$} & \multirow{2}{*}{$\begin{array}{l}\text { Supervision of } \\
\text { Finance Director }\end{array}$} \\
\hline $\begin{array}{l}\text { Positioned in } \\
\text { Performance and/or } \\
\text { Quality Department }\end{array}$ & $14 \%$ & & & & & & & \\
\hline $\begin{array}{c}\text { Supervision of } \\
\text { Chief Executive } \\
\text { Director }\end{array}$ & $100 \%$ & $\begin{array}{c}\text { Cross- } \\
\text { functional } \\
\text { Vision } \\
\end{array}$ & $1 \%$ & & \multirow{2}{*}{$14 \%$} & \multirow{2}{*}{$\begin{array}{l}\text { Isolation from } \\
\text { Key Actors }\end{array}$} & \multirow{2}{*}{$100 \%$} & \multirow{2}{*}{$\begin{array}{l}\text { Supervision of } \\
\text { Finance Director }\end{array}$} \\
\hline $\begin{array}{c}\text { Positioned in } \\
\text { Performance and/or } \\
\text { Quality Department }\end{array}$ & $100 \%$ & $\begin{array}{l}\text { Strategic } \\
\text { Vision }\end{array}$ & $1 \%$ & & & & & \\
\hline $\begin{array}{c}\text { Number of } \\
\text { instances }\end{array}$ & & 73 & $70 \%$ & 104 & $30 \%$ & 31 & & $\begin{array}{l}\text { Number of } \\
\text { instances }\end{array}$ \\
\hline $\begin{array}{c}\text { Supervision of } \\
\text { Finance Director }\end{array}$ & $96 \%$ & & & \multirow{4}{*}{$\begin{array}{l}\text { Shaping of } \\
\text { Event } \\
\text { Schemas }\end{array}$} & & & & Supervision of \\
\hline $\begin{array}{c}\text { Positioned in } \\
\text { Performance and/or } \\
\text { Quality Department }\end{array}$ & $4 \%$ & $\begin{array}{l}\text { Enhanced } \\
\text { Collaboration }\end{array}$ & $70 \%$ & & $3 \%$ & $\begin{array}{l}\text { Dampened } \\
\text { Collaboration }\end{array}$ & $100 \%$ & $\begin{array}{l}\text { Chief Executive } \\
\text { Director }\end{array}$ \\
\hline $\begin{array}{l}\text { Supervision of } \\
\text { Finance Director }\end{array}$ & $100 \%$ & $\begin{array}{c}\text { Broadening of } \\
\text { Tasks }\end{array}$ & $5 \%$ & & $1 \%$ & $\begin{array}{c}\text { Broadening of } \\
\text { Tasks }\end{array}$ & $100 \%$ & Other Positions \\
\hline $\begin{array}{c}\text { Positioned in a } \\
\text { Department of } \\
\text { Management } \\
\text { Control } \\
\end{array}$ & $100 \%$ & $\begin{array}{l}\text { Smooth Work } \\
\text { Process }\end{array}$ & $3 \%$ & & $18 \%$ & $\begin{array}{l}\text { Prescription } \\
\text { of Tasks }\end{array}$ & $100 \%$ & $\begin{array}{l}\text { Supervision of } \\
\text { Finance Director }\end{array}$ \\
\hline $\begin{array}{c}\text { Number of } \\
\text { instances }\end{array}$ & & 60 & $78 \%$ & 77 & $22 \%$ & 17 & & $\begin{array}{c}\text { Number of } \\
\text { instances }\end{array}$ \\
\hline Total of instances & & 144 & $70 \%$ & 207 & $30 \%$ & 63 & & Total of instances \\
\hline
\end{tabular}

* Contribution of 1st Order Category to 2nd Order Themes ** Contribution of 2nd Order Themes to Aggregate Dimensions 


\section{APPENDIX A}

\section{Typified Situations Identified by Focus Group Members}

\begin{tabular}{|c|c|}
\hline Factsheet 1 & Organizing corporate governance \\
\hline Factsheet 2 & Scheduling the implementation of corporate governance \\
\hline Factsheet 3 & Mobilizing the actors of corporate governance \\
\hline Factsheet 4 & Setting targets in terms of activities, revenues and resources \\
\hline Factsheet 5 & $\begin{array}{l}\text { Elaborating contracts with the hospital's departments and endowing } \\
\text { actors with responsibilities }\end{array}$ \\
\hline Factsheet 6 & Delegating management \\
\hline Factsheet 7 & Setting up management reviews \\
\hline Factsheet 8 & Defining profit-sharing mechanisms \\
\hline Factsheet 9 & $\begin{array}{l}\text { Learning from experience to adjust corporate governance } \\
\text { mechanisms }\end{array}$ \\
\hline Subtheme 10 & Elaborating scoreboards \\
\hline Factsheet 11 & Choosing the right type of scoreboards \\
\hline Factsheet 12 & Elaborating strategic scoreboards \\
\hline Factsheet 13 & Elaborating scoreboards for the hospital's departments \\
\hline Factsheet 14 & Defining a model and a scope of analysis for income statements \\
\hline Factsheet 15 & Allocating revenues from medical, surgical and obstetrical stays \\
\hline Factsheet 16 & Allocating revenues from stays in psychiatry \\
\hline Factsheet 17 & Allocating revenues from subacute and rehabilitative care \\
\hline Factsheet 18 & Allocating subsidies \\
\hline Factsheet 19 & Calculating and allocating revenues from outpatients \\
\hline Factsheet 20 & Allocating revenues from additional activities \\
\hline Factsheet 21 & Valuing internal services \\
\hline Factsheet 22 & Allocating staff expenditure \\
\hline Factsheet 23 & Allocating medical costs \\
\hline Factsheet 24 & Allocating accommodation and catering costs \\
\hline Factsheet 25 & Allocating other expenditures \\
\hline Factsheet 26 & Building a switching structure for indirect costs \\
\hline Factsheet 27 & Choosing and collecting work units \\
\hline Factsheet 28 & Cross-checking data \\
\hline Factsheet 29 & Evaluating the economic impacts of a medical project \\
\hline Factsheet 30 & Benchmarking performance \\
\hline Factsheet 31 & Using innovating cost-analysis methods: the example of ABC \\
\hline Factsheet 32 & Analyzing operational processes \\
\hline
\end{tabular}

